\title{
Analisis Praktik Keluarga Berencana pada Wanita Karir di Kecamatan Cilamaya Kulon Kabupaten Karawang Perspektif Maslahah Mursalah
}

\author{
Dea Sa'adah *, Amrullah Hayatudin \\ Prodi Hukum Keluarga Islam, Fakultas Syariah, Universitas Islam \\ Bandung, Indonesia. \\ *Dheasaadah36@gmail.com, Amrullahhayatudin@gmail.com
}

\begin{abstract}
The massive progress of the times has pushed people to create contraceptives to regulate pregnancy and many women go out of their homes for careers or work, even though Islam only requires men (husbands) to earn a living. This study was conducted to determine the concept of maslahah mursalah in determining Islamic law, family planning practices for career women in the Cilamaya Kulon sub-district, Karawang regency, the perspective of maslahah mursalah. This study uses a descriptive qualitative analysis method, the primary data source is obtained from career women who have family planning through interviews and secondary data from related literature studies. The results of the study explained that the concept of maslahah mursalah is the absence of textual arguments that regulate a benefit that does not conflict with the objectives of the Shari'a. Most of the family planning acceptors in Cilamaya Kulon Sub-district chose to use family planning based on motives that contained maslahah, doing a safe way to space the time of pregnancy. It can be concluded that the practice of family planning in career women in Cilamaya Kulon District, Karawang Regency is a problem. Family planning is legally permissible in Islam, provided that it only regulates births that do not violate nature (tanzhim an-nasl) not restricts offspring for fear of poverty and other problems that arise as a result of having many children (tahdid an-nasl).
\end{abstract}

Keywords: Family Planning, Career Women, Maslahah Wursalah.

\begin{abstract}
Abstrak. Kemajuan zaman yang masif mendorong manusia menciptakan alat kontrasepsi untuk mengatur kehamilan dan banyak dari kalangan wanita pergi keluar rumah untuk berkarir atau bekerja, padahal islam hanya mewajibkan laki-laki (suami) lah yang mencari nafkah. Penelitian ini dilakukan untuk mengetahui konsep maslahah mursalah dalam penentuan hukum islam, praktik KB pada wanita karir di kecamatan Cilamaya Kulon Kabupaten Karawang perspektif maslahah mursalah, tujuan penelitian adalah menjawab rumusan penelitian di atas. Penelitian ini menggunakan metode deskriptif analisis kualitatif, sumber data primer diperoleh dari wanita karir yang ber KB melalui wawancara dan data sekunder dari studi pustaka terkait. Hasil penelitian dijelaskan bahwa konsep maslahah mursalah adalah tidak adanya dalil nash yang mengatur suatu kemaslahatan yang tidak bertentangan dengan tujuan syariat. Sebagian besar akseptor KB di Kecamatan Cilamaya Kulon memilih menggunakan KB dilatarbelakangi motif yang mengandung maslahah, melakukan cara yang aman untuk menjarangkan waktu kehamilan. Dapat disimpulkan bahwa praktik keluarga berencana pada wanita karir di Kecamatan Cilamaya Kulon Kabupaten Karawang merupakan maslahah. Keluarga Berencana hukumnya diperbolehkan dalam islam, dengan syarat hanya mengatur kelahiran yang tidak menyalahi kodrat (tanzhim an-nasl) bukan membatasi keturunan karena takut akan kemiskinan dan permasalahan lain yang muncul akibat memiliki banyak anak (tahdid an-nasl). Hukum kebolehan tanzhim an-nasl dikarenakan tanzhim an-nasl tidak bertentangan dengan kodrat nurani manusia yang menyukai bangga dengan banyaknya keturunan. Kebolehan tanzhim an-nasl berdasarkan 'ijma ulama, AlQur'an, Al-Hadis, Qiyas, dan Istishab.
\end{abstract}

Kata Kunci: Keluarga Berencana, Wanita Karir, Maslahah Mursalah. 


\section{A. Pendahuluan}

Keluarga Berencana merupakan tindakan membantu individu atau pasangan suami istri untuk menghindari kelahiran yang tidak diinginkan, mendapatkan kelahiran yang memang diinginkan, mengatur interval diantara kelahiran. KB adalah proses yang disadari oleh pasangan untuk memutuskan jumlah dan jarak anak serta waktu kelahiranDidukung dengan munculnya alat-alat kontrasepsi modern yang telah banyak dikenal oleh seluruh kalangan. Kebijakan program Keluarga Berencana secara nyata berkontribusi untuk membantu para ibu yang bekerja meningkatkan kesejahteraan warga negara baik dari segi ekonomi, sosial, pendidikan dengan menekan laju kelahiran.

Tujuan Keluarga Berencana meningkatkan kesejahteraan ibu dan anak serta mewujudkan keluarga kecil yang bahagia dan sejahtera melalui pengendalian kelahiran dan pengendalian pertumbuhan penduduk Indonesia. Di samping itu KB diharapkan dapat menghasilkan penduduk yang berkualitas, sumber daya manusia yang bermutu dan meningkatkan kesejahteraan keluarga. Sasaran dari program KB, meliputi sasaran langsung, yaitu pasangan usia subur yang bertujuan untuk menurunkan tingkat kelahiran dengan cara penggunaan kontrasepsi secara berkelanjutan, dan sasaran tidak langsung yang terdiri dari pelaksana dan pengelola $\mathrm{KB}$, dengan cara menurunkan tingkat kelahiran melalui pendekatan kebijaksanaan kependudukan terpadu dalam rangka mencapai keluarga yang berkualitas, keluarga sejahtera.

Salah satu wilayah yang banyak menjalankan program KB adalah Kecamatan Cilamaya Kulon, menurut Badan Pusat Statistik Kabupaten Karawang pada tahun 2020, terdapat 10,622 KK jumlah akseptor KB. Sementara untuk KB tidak ada satu ayat pun di dalam Al-Qur'an yang secara terang-terangan menjelaskan bahwa mengatur jarak kelahiran anak adalah haram Islam sebagai agama yang sempurna mengharuskan segala sesuatu dilakukan secara baik terlebih masalah penerapan hukum Islam tentunya harus dilakukan dengan benar dan penuh dengan tanggung jawab agar semua pihak merasa nyaman dan aman tanpa ada yang ditutup-tutupi.

Keluarga muslim di masa sekarang telah mengalami banyak perubahan dalam kehidupan berkeluarga, salah satunya dengan lebih banyak istri yang berpendidikan dan bekerja untuk meningkatkan finansial. Didukung dengan munculnya alat-alat kontrasepsi modern yang telah banyak dikenal oleh seluruh kalangan. Kebijakan program Keluarga Berencana secara nyata berkontribusi untuk membantu para ibu yang bekerja meningkatkan kesejahteraan warga negara baik dari segi ekonomi, sosial, pendidikan dengan menekan laju kelahiran.

Oleh karenanya, dalam menentukan suatu hukum harus diperhatikan aspek kemaslahatan. Walaupun di dalam ketentuan hukum tidak ada syarat dan ketentuan yang mengharuskan adanya maslahah, tetapi untuk menentukan suatu hukum kita perlu memperhatikan aspek maslahah mursalah. Agar tidak menimbulkan mudharat atau kerugian bagi yang lainnya.

\section{B. Metodologi Penelitian}

1. Pendekatan Penelitian

Pendekatan penelitian yang digunakan adalah pendekatan fenomenologi. Pendekatan fenomenologi digunakan untuk mengungkap praktik keluarga berencana pada masyarakat kecamatan Cilamaya Kulon Kabupaten Karawang dan mengungkap makna yang terkandung di dalamnya mengenai latar belakang, motif, dan tujuan memilih menggunakan KB. Dalam hal ini adalah berupaya mengungkap tentang wanita karir yang memilih menggunakan KB di Kecamatan Cilamaya Kulon, kemudian hasil observasi ditelaah dengan sumber kepustakaan untuk ditarik kesimpulan.

2. Jenis Data Penelitian

Penelitian ini menggunakan dua jenis data penelitian yaitu:

a. Studi Pustaka (Library Research), yaitu data penelitian yang diperoleh peneliti dari dokumentasi, laporan, buku, atau hasil penelitian lain yang bersifat kepustakaan, yang membahas tentang keluarga berencana, wanita karir, maslahah mursalah, dan informasi yang terkait dengan penelitian.

b. Studi Lapangan (Field Research), yaitu data yang diperoleh peneliti berkaitan dengan 
objek penelitian penelitian secara langsung di lapangan yang pada penelitian ini dilakukan di wilayah Kecamatan Cilamaya Kulon Kabupaten Karawang. Data disajikan dalam bentuk hasil survei atau observasi lapangan.

3. Sumber Data Penelitian

a. Sumber data primer, diperoleh langsung dari wanita karir yang telah menikah, dan sedang menggunakan alat kontrasepsi KB di wilayah kecamatan Cilamaya Kulon Kabupaten Karawang.

b. Sumber data sekunder, diperoleh dari penelitian kepustakaan diperoleh peneliti dari dokumentasi, regulasi, laporan, buku, atau hasil penelitian lain yang bersifat kepustakaan, yang membahas tentang keluarga berencana, wanita karir, maslahah mursalah, dan informasi yang terkait dengan penelitian.

Teknik Pengumpulan Data

Pada penelitian skripsi ini penulis dalam pengumpulan data, untuk memperoleh data yang dikehendaki, dilakukan dengan melakukan wawancara langsung maupun via google form dengan beberapa narasumber terkait, kemudian hasil wawancara ditelaah dengan membaca, menela'ah, menganalisa sumber data sekunder untuk kemudian ditarik kesimpulan.

a. Data Primer

Data Primer menggunakan data dari wawancara yang dilakukan dengan para narasumber yaitu wanita karir yang memilih menggunakan KB di Kecamatan Cilamaya Kulon Kabupaten Karawang. 10 sampel dianggap cukup untuk menggambarkan populasi secara keseluruhan, responden penelitian ini adalah istri.

b. Data Sekunder

Pemilihan teknik data sekunder berupa internal data yaitu faktor kontekstual, struktural, dan perilaku objek penelitian. Serta eksternal data yaitu buku-buku, jurnal, regulasi, publikasi pemerintah dan lainnya.

4. Teknik Analisis Data

Teknik analisis data penelitian yang digunakan pada penelitian kali ini adalah pendekatan penelitian kualitatif, digunakan untuk meneliti pada kondisi objek yang alamiah dimana peneliti adalah sebagai instrumen kunci, pengambilan sampel sumber data dilakukan secara purposive sampling yaitu dengan menentukan kriteria-kriteria tertentu. Analisis data bersifat kualitatif. Metode penelitian kualitatif yang bermaksud untuk memahami fenomena tentang apa yang dialami oleh subjek penelitian dengan menelaah persepsi, motivasi, tindakan, dan lain-lain.

Langkah-langkah yang digunakan untuk mendapatkan data adalah:

\section{Observasi}

Merupakan metode yang digunakan oleh peneliti dimana peneliti menelaah atau mengamati langsung terhadap narasumber yang diteliti. Dalam hal ini adalah wanita karir yang melakukan KB di Kecamatan Cilamaya Kulon.

2. Wawancara

Wawancara adalah pertemuan antara peneliti dan narasumber atau responden, jawaban dari narasumber adalah masih berupa data mentah. Langkah-langkah melakukan wawancara dilakukan dengan peneliti mengajukan pertanyaan-pertanyaan dan narasumber memberikan jawaban, peneliti menggunakan alat bantu pedoman wawancara yang berisi catatan penting mengenai pokok-pokok yang akan ditanyakan sesuai tujuan yang dikehendaki.

Beberapa tahapan-tahapan dalam menganalisis data mulai dari sebelum, saat pengambilan/pengumpulan data, dan saat setelah pengumpulan data. Tahapan-tahapan atau alur analisis data terdiri dari Reduksi data, penyajian data, dan verifikasi data.

Reduksi data merupakan tahapan yang dilakukan dengan memilih, menyederhanakan dan mengabstrakkan secara terus-menerus hingga diperoleh kesimpulan. Penyajian data merupakan tahapan yang dilakukan untuk mengumpulkan informasi yang berkaitan dengan penelitian, penyajian data dapat berupa bagan, grafik, dan lainnya. Verifikasi data atau dapat disebut dengan kesimpulan adalah tahapan untuk menyimpulkan data-data informasi yang berkaitan dengan penelitian dengan dasar validitas atau kebenaran yang dapat dipertanggung 
jawabkan.

Analisis wawancara dilakukan terhadap informasi yang didapat dari hasil wawancara. penyajiannya dapat dilakukan dalam bentuk narasi hasil wawancara yang akan memudahkan dalam memahami apa yang terjadi, peneliti pada langkah ini berusaha menyusun data yang relevan hingga dapat menjadi informasi yang dapat disimpulkan dan memiliki makna.

Proses dalam menyelesaikan penelitian dilakukan dengan menampilkan dan membuat hubungan antar fenomena untuk mengetahui apa yang terjadi dan perlu ditindak lanjuti untuk tercapainya tujuan penelitian, terakhir adalah menarik kesimpulan berdasarkan hasil temuan yang didapatkan dan melakukan verifikasi data.

\section{Hasil Penelitian dan Pembahasan}

\section{Konsep Maslahah Mursalah dalam Penentuan Hukum Islam}

Inti dari konsep maslahah mursalah adalah tidak adanya dalil nash yang mengatur suatu peristiwa yang di dalamnya terdapat kemaslahatan yang tidak bertentangan dengan tujuan syariat. Nash tidak mengatur atau membicarakan kemaslahatan tersebut, baik dalam bentuk menetapkan hukumnya, memerintahkan mewujudkannya, maupun melarang memperhatikannya.

Penggalian hukum dengan metode maslahah mursalah disebut dengan istislah, yang merupakan sebuah konsep dalam pemikiran hukum islam yang menjadikan maslahah (kebutuhan manusia) yang sifatnya tidak terikat (mursalah) menjadi suatu sumber hukum sekunder, oleh karenanya konsep ini lebih dikenal dengan al-maslahah mursalah atau almashalihal - mursalah.

Konsep ini mulanya dikembangkan dalam aliran mazhab Malikiyah. Hanafiyah mengistilahkan maslahah mursalah dengan "istihsan dharurat."

Istihlah adalah istidlal (pencarian dalil) dengan menggunakan al-maslahah al-mursalah yang belum ada dalil hukum secara khusus tetapi terdapat dalam dalil umum, syariat memelihara kemaslahatan mahluk dan seluruh hukum-hukum yang disyariatkan untuk mewujudkannya, menghindari kerusakan dan kesulitan baik secara material maupun immaterial, yang sudah maupun belum terjadi. Dalam kitab Fathul Bari Ibnu hajar menjelaskan bahwa Rasulullah SAW menyukai amalan-amalan yang tidak memberatkan umat-Nya, agar umatnya tidak terbebani dalam menjalankan syariat, karena sesungguhnya amalan yang membuat umat takut untuk menjalaninya merupakan amalan masyaqqah (memberatkan).

Kebolehan maslahah mursalah merujuk pada adanya takrir (pengakuan) Rasulullah atas penjelasan Mu'az ibn Jabal yang akan menggunakan ijtihad bi al-ra'yi bila tidak menemukan ayat Alquran dan sunnah untuk menyelesaikan sebuah kasus hukum. Penggunaan maslahah mursalah begitu meluas di kalangan sahabat sebagai suatu keadaan yang diterima bersama oleh para sahabat. Contohnya pada saat pemilihan Abu Bakar As-Shidiq sebagai khalifah yang dilakukan oleh sahabat-sahabat Rasulullah, pencetakan mata uang dan pembentukan dewan-dewan di masa Umar bin Khattab.

Tidak ada nash yang memerintahkan atau melarang perwujudan kemaslahan yang terkandung didalamnya, maka para ulama berbeda pendapat mengenai kebolehan penggunaannya sebagai dalil syara', sebagian ada yang menerima dan sebagian lain menolaknya.

Jumhur ulama menerimanya sebagai dalil syara' diantaranya karena ke-maslahatan manusia terus berkembang dan bertambah mengikuti perkembangan kebutuhan manusia, apabila ke-maslahatan yang berkembang tidak diperhatikan dan hanya melihat ke-maslahatan dalam nash saja, maka akan banyak ke-maslahatan yang ditempat dan masa yang datang kemudian akan mengalamami kekosongan hukum dan syariat sendiri tidak dapat mengikuti perkembangan manusia, padahal tujuan syariat adalah untuk mewujudkan ke-maslahatan manusia di setiap tempat dan masa.

\section{Praktik Keluarga Berencana pada Wanita Karir di Kecamatan Cilamaya Kulon Kabupaten Karawang Perspektif Maslahah Mursalah}

Dari sumber data 10 responden terkait praktik Keluarga Berencana pada wanita karier dapat 
menggambarkan bahwa faktor-faktor yang melatarbelakangi penggunaan KB disebabkan karena berbagai macam alasan, ada yang ingin mengatur jumlah anak, mengatur jarak kelahiran anak, ingin fokus berkarier/bekerja, dan ada pula dilatarbelakangi ingin berdua dahulu dengan suami.

Hasil dari penelitian yang dilakukan, sebagian besar akseptor memilih menggunakan KB dilatarbelakangi oleh motif atau alasan yang mengandung maslahah, melakukan suatu cara yang tidak membahayakan agar dapat menjarangkan waktu kehamilan atau kelahiran buah hati, dimana hasil dari penjarangan secara sosial kemasyarakatan bertujuan untuk menekan meledaknya populasi penduduk secara tidak terkontrol. Dari penelitian ini dapat disimpulkan bahwa praktik keluarga berencana pada wanita karir di Kecamatan Cilamaya Kulon Kabupaten Karawang merupakan maslahah.

Sedangkan motif responden memilih berkarir/bekerja umumnya adalah untuk membantu perekonomian keluarga, untuk masa depan anak, memiliki passion dalam berkarir, dan memanfaatkan gelar yang sudah didapat.

\section{Tinjauan Maslahah Mursalah terhadap Fenomena Keluarga Berencana}

Dari analisis peneliti menyimpulkan bahwa manfaat program keluarga berencana termasuk ke dalam objek maslahah mursalah, karena manfaat-manfaat keluarga berencana jelas dapat dirasakan oleh orang banyak bukan hanya segelintir orang, kemudian syariat islam pun menyeru kepada manusia untuk meraih kemaslahatan dan mencegah ke-mudharatan.

Setelah melakukan penelitian tentang mudhorot dari kontrasepsi di kecamatan Cilamaya Kulon, peneliti mendapatkan kesimpulan bahwa KB tidak memiliki efek yang bersifat merugikan. Beberapa akseptor yang menggunakan $\mathrm{KB}$ mengeluh tentang rasa pusing dan mual atau ketidaknyamanan akibat KB hanya bersifat sementara, gangguan terhadap gairah seksual hanya bersifat psikologis bukan gejala fisiologis. Sedangkan efek haid tidak teratur pada penggunaan KB suntik dapat disiasati dengan mengganti pada jenis KB lain.

Begitupun tentang memilih menjadi wanita karir, semua responden merasakan manfaat positif diantaranya dapat membantu menambah penghasilan keluarga, menambah produktifitas dan kreatifitas diri, memanfaatkan gelar yang sudah di dapat, dan menyalurkan passion dalam berkarir, responden merasa senang dan nyaman dalam menjalankan KB sekaligus berkarir, asalkan tidak menyalahi hukum syara dan mendapat izin suami, maka keduanya mengandung maslahah.

Syarat manfaat dapat dikategorikan maslahah mursalah adalah sebagai berikut:

1. Harus berupa manfaat faktual (haqiqiyyah qot'iyyah) bukan berupa manfaat yang bersifat dugaan (wahmiyyah).

2. Harus berupa manfaat kepentingan umum ('ammah kulliyyah) bukan manfaat yang bersifat personal (khasah).

3. Harus selaras dengan prinsip-prinsip umum yang telah ditetapkan nash atau ijma.

Ditinjau dari tiga syarat di atas menurut analisis peneliti semua dari manfaat keluarga berencana termasuk dalam manfaat maslahah mursalah. Tujuan pokok dari keluarga berencana adalah untuk mengendalikan pertumbuhan laju penduduk namun tidak sampai merusak sisi kemanusiaan itu sendiri, manusia tetap dapat menyalurkan kebutuhan biologisnya dan dapat kembali mendapatkan anak apabila berhenti memakai $\mathrm{KB}$, berbeda dengan kebiri atau sterilisasi yang mampu menghentikan laju pertumbuhan penduduk tetapi memiliki konsekuensi tidak dapat menyalurkan kebutuhan biologis dan secara mutlak tidak dapat mempunyai keturunan setelahnya, unsur ini yang menyebabkan kebiri mutlak diharamkan. Keluarga berencana apabila dilakukan dengan standar prosedur yang benar tidak akan menimbulkan efek samping yang serius bagi penggunanya.

Selain itu semua manfaat yang telah disebutkan juga bersifat umum (maslahah 'ammah) karena manfaat dirasakan oleh seluruh akseptor keluarga berencana bukan hanya satu orang saja. Manfaat ini menyangkut kemaslahatan orang banyak baik untuk istri, suami, anak, dan masyarakat umum. Dan yang paling utama manfaat-manfaat tersebut selaras dengan secara umum yakni suami istri ber-KB tetap dapat menyalurkan kebutuhan biologis dan menjaga kesehatan serta kesejahteraan dalam berumah tangga. 
Dari pemaparan di atas jelas bahwasanya Keluarga Berencana merupakan objek kajian maslahah mursalah. Keluarga berencana mengandung kemaslahatan dimana KB sebagai pengaturan kelahiran dengan usaha mencegah kehamilan sementara atau bahkan selamanya dalam situasi dan kondisi tertentu, baik bagi keluarga akseptor maupun untuk kepentingan masyarakat dan negara.

Keluarga berencana berdasarkan tujuannya terbagi menjadi dua yaitu: tahdid an-nasl dan tanzhim an-nasl. Mahmud Syaltut mengharamkan tahdid an-nasl dikarenakan tujuan dari tahdid an-nasl adalah untuk membatasi keturunan, sehingga pembatasan keturunan pada jumlah tertentu adalah haram. Keharaman tahdid an-nasl berdasarkan 'ijma ulama, Al-Qur'an, AlHadis, Qiyas, dan Istishab.

Hukum kebolehan tanzhim an-nasl dikarenakan tanzhim an-nasl tidak bertentangan dengan kodrat nurani manusia yang menyukai bangga dengan banyaknya keturunan. Kebolehan tanzhim an-nasl berdasarkan 'ijma ulama, Alqur'an, Al-hadis, Qiyas, dan Istishab.

\section{Kesimpulan}

Berdasarkan pembahasan dalam penelitian ini, peneliti menyimpulkan beberapa hasil penelitian sebagai berikut:

1. Penggalian hukum dengan metode maslahah mursalah disebut dengan istislah, yang merupakan sebuah konsep dalam pemikiran hukum islam yang menjadikan maslahah (kebutuhan manusia) yang sifatnya tidak terikat (mursalah) menjadi suatu sumber hukum sekunder, oleh karenanya konsep ini lebih dikenal dengan al-maslahah mursalah atau al-mashalihal - mursalah.

Istihlah adalah istidlal (pencarian dalil) dengan menggunakan al-maslahah almursalah yang belum ada dalil hukum secara khusus tetapi terdapat dalam dalil umum, syariat memelihara kemaslahatan mahluk dan seluruh hukum-hukum yang disyariatkan untuk mewujudkannya, menghindari kerusakan dan kesulitan baik secara material maupun immaterial, yang sudah maupun belum terjadi. Dalam kitab Fathul Bari Ibnu hajar menjelaskan bahwa Rasulullah SAW menyukai amalan-amalan yang tidak memberatkan umat-Nya, agar umatnya tidak terbebani dalam menjalankan syariat, karena sesungguhnya amalan yang membuat umat takut untuk menjalaninya merupakan amalan masyaqqah (memberatkan).

2. Hasil dari penelitian yang dilakukan, sebagian besar akseptor memilih menggunakan $\mathrm{KB}$ dilatarbelakangi oleh motif atau alasan yang mengandung maslahah, melakukan suatu cara yang tidak membahayakan agar dapat menjarangkan waktu kehamilan atau kelahiran buah hati, dimana hasil dari penjarangan secara sosial kemasyarakatan bertujuan untuk menekan meledaknya populasi penduduk secara tidak terkontrol. Dari penelitian ini dapat disimpulkan bahwa praktik keluarga berencana pada wanita karir di Kecamatan Cilamaya Kulon Kabupaten Karawang merupakan maslahah. Keluarga Berencana dan wanita karier merupakan objek kajian maslahah mursalah. Keluarga berencana mengandung kemaslahatan dimana KB sebagai pengaturan kelahiran dengan usaha mencegah kehamilan sementara atau bahkan selamanya dalam situasi dan kondisi tertentu, baik bagi keluarga akseptor maupun untuk kepentingan masyarakat dan negara. Penggalian hukum dengan metode maslahah mursalah disebut dengan istislah, yang merupakan sebuah konsep dalam pemikiran hukum islam yang menjadikan maslahah (kebutuhan manusia) yang sifatnya tidak terikat (mursalah) menjadi suatu sumber hukum sekunder, oleh karenanya konsep ini lebih dikenal dengan al-maslahah mursalah atau al-mashalihal-mursalah.

\section{Acknowledge}

Ucapan terimakasih saya ucapkan kepada semua pihak yang telah membantu dalam menyelesaikan Tugas Akhir SKRIPSI ini, terutama kepada:

1. Allah SWT yang selalu memberikan nikmat kesehatan, nikmat rezeki, dan semua nikmat yang tidak terhingga.

2. Orang tua Saya, Bapa Warcita, dan Ibu Hj. Kasem yang tidak pernah lelah untuk 
berjuang demi anaknya, selalu mendoakan, selalu memberikan motivasi agar Saya selalu semangat dalam kuliah dan selalu mendukung Saya dalam menyelesaikan Skripsi ini.

3. Kedua kakak kandung saya, Lukman Hakim dan Arif Munandar yang selalu memberikan support terbaik untuk adiknya baik berupa materi, tenaga, dan pikiran sampai bisa berada di titik ini.

4. Dr. Amrullah Hayatudin S.HI., M.Ag, dan Dr. Shindu Irwansyah Lc., M. Ag., selaku dosen pembimbing 1 dan 2, yang telah bersedia meluangkan waktu dan ilmu nya untuk selalu membimbing saya dengan sangat baik dalam proses penyelesaian Skripsi ini.

5. Seluruh keluarga besar $\mathrm{H}$. Ratim dan $\mathrm{Hj}$. Resih, yang selalu memberikan dukungan do'a dan semangat selama proses penyusunan tugas akhir Skripsi.

6. Calon suami saya Saif Alparisi beserta keluarga yang telah memberikan motivasi dan dukungan agar dapat menyelesaikan Skripsi dengan baik dan tepat waktu.

7. Sohib Till Jannah, yang telah memberikan support sejak awal memasuki dunia perkuliahan sampai menuju wisuda.

8. Sahabat dan teman-teman Saya semua yang selalu memberikan semangat selama proses penyusunan tugas akhir Skripsi ini. Serta kepada rekan-rekan seperjuangan di Prodi Hukum Keluarga Islam Angkatan 2018 semuanya.

\section{Daftar Pustaka}

[1] Sirait, L. I. (2021). Buku Ajar Asuhan Keluarga Berencana Pelayanan Alat Kontrasepsi. Insan Cendekia Mandiri.

[2] Pemerintah Kabupaten Karawang, Profile Cilamaya Kulon, - Penelusuran Google. (n.d.). Retrieved January 5, 2022.

[3] Paturrahman, A. (2001). Konsep badan kependidikan dan keluarga berencana nasional (BKKBN) tentang keluarga berencana (KB) di tinjau dari hukum Islam dan hukum positif.

[4] Faadhillah, F., Surahman, M., \& Hayatudin, A. (2020). Tinjauan Maslahah Mursalah terhadap Penggunaan Transportasi Online "Grabwheels". Prosiding Hukum Ekonomi Syariah, 6(2), 118-121.

[5] Hayatudin, A. (2019). Ushul fiqh: jalan tengah memahami Hukum Islam.

[6] Rusfi, M. (2014). Validitas Maslahah Mursalah Sebagai Sumber Hukum. Al-'Adalah, 12(1), 63-74.

[7] Lutfi, M. (2021). Wanita Karir Sebagai Dasar Penggunaan Alat Kontrasepsi Spiral (Analisis Maqasid al-Syariah dan Gender). Jurnal Al-Ahkam: Jurnal Hukum Pidana Islam, 3(1), 37-52.

[8] SITI ERMWATI, S. E. (2016). Peran ganda wanita karier (konflik peran ganda wanita karier ditinjau dalam prespektif islam). EDUTAMA, 2(2), 59-69.

[9] Adinugraha, H. H., \& Mashudi, M. (2018). Al-Maslahah al-mursalah dalam penentuan hukum Islam. Jurnal Ilmiah Ekonomi Islam, 4(01), 63-75. 